\title{
Pengetahuan, Sikap, dan Perilaku Masyarakat Tentang Aspek Pencegahan dan Pengendalian Demam Berdarah Dengue di Kota Prabumulih, Sebelum dan Sesudah Intervensi Pemberdayaan Masyarakat

\author{
Knowledge, Attitude and Practice of Community Towards Dengue \\ Prevention and Control in Prabumulih City, Before and After \\ Community Empowerment Intervention
}

Lasbudi P. Ambarita*, Milana Salim, Hotnida Situorus, dan Rika Mayasari Balai Litbang Kesehatan Baturaja, Badan Litbang Kesehatan, Kementerian Kesehatan RI Jl. A. Yani KM. 7, Kemelak, Baturaja 32111, Sumatra Selatan, Indonesia

INFO ARTIKEL

\section{Article History:}

Received: 30 Apr 2019

Revised: 04 Sep 2019

Accepted: 02 Okt 2019

\section{Kontribusi:}

Lasbudi P. Ambarita sebagai Kontributor Utama dalam artikel ini. Milana Salim, Hotnida Sitorus, dan Rika Mayas ari sebagai Kontributor Anggota.

Keywords:

Knowledge

Attitude

Practice

Prabumulih

Community empowerment

Kata kunci:

Pengetahuan

Sikap

Perilaku

Prabumulih

Pemberdayaan Masyarakat

\section{A B S T RACT / A B S T RAK}

Dengue hemorrhagic fever (DHF) in South Sumatra Province especially Prabumulih in recent years has not shown a significant decline. This research aims to assess community's level of knowledge, attitudes and practice with regards to empowerment of cadres and community group as an intervention variable. There were three location of research, first location with intervention of empowerment of cadre and community group, second location with cadre empowerment and the third location without intervention. The data collected in this research is knowledge, attitude and practice of the community before and after the intervention provided. The results showed there is an average level difference of knowledge, but statistically difference occurred on the knowledge and practice in an area with an intervention empowerment of cadres and local community groups. Local community groups such as religious group, social gathering, youth organization, etc can be an effective target for increasing knowledge about disease prevention aspects of DHF, raises awareness and triggered behavior change collectively.
Demam Berdarah Dengue (DBD) di Provinsi Sumatra Selatan khususnya Kota Prabumulih dalam beberapa tahun terakhir belum menunjukkan penurunan yang signifikan. Penelitian ini bertujuan untuk mengetahui dampak dari intervensi pemberdayaan kader dan kelompok masyarakat terhadap tingkat pengetahuan, sikap dan perilaku masyarakat. Intervensi yang diberikan pada penelitian ini adalah satu wilayah dengan intervensi pemberdayaan kader jumantik dan kelompok ibu-ibu pengajian, wilayah yang kedua dengan intervensi pemberdayaan kader jumantik, dan wilayah yang ketiga tanpa diberikan intervensi. Data yang dikumpulkan dalam penelitian ini adalah pengetahuan, sikap dan perilaku masyarakat sebelum dan sesudah intervensi diberikan. Hasil penelitian menunjukkan terdapat perbedaan rata-rata tingkat pengetahuan, sikap dan perilaku masyarakat antara sebelum dan sesudah intervensi, namun secara statistik perbedaan yang bermakna terjadi pada aspek pengetahuan dan perilaku di daerah dengan intervensi pemberdayaan kader dan kelompok masyarakat lokal. Kelompok masyarakat lokal seperti kelompok pengajian, arisan, karang taruna dan sebagainya dapat menjadi sasaran efektif untuk meningkatkan pengetahuan masyarakat tentang aspek pencegahan penyakit DBD, menimbulkan kesadaran dan memicu terjadinya perubahan perilaku secara kolektif.

(C) 2020 Jurnal Vektor Penyakit. All rights reserved

*Alamat Korespondensi : email : lasbudiT4@gmail.com

\section{PENDAHULUAN}

Penyakit Demam Berdarah Dengue (DBD) merupakan salah satu penyakit tular nyamuk (mosquito-borne disease) yang hingga saat ini masih menjadi problem kesehatan. Dengue merupakan penyakit tular-nyamuk yang paling cepat menyebar, menurut Badan
Kesehatan Dunia (WHO) selama 50 tahun terakhir terjadi peningkatan kasus 30 kali lipat termasuk meningkatnya sebaran geografis ke berbagai wilayah, dan saat ini pola penyebaran telah terjadi dari kawasan perkotaan ke pedesaan. Lebih dari 2,5 milyar penduduk dunia, atau lebih dari $40 \%$ 
populasi berisiko tertular dengue. Badan kesehatan dunia mengestimasi sekitar 50 hingga 100 juta infeksi dengue setiap tahun.

Penyebaran kasus DBD di Indonesia hingga tahun 2015 telah terjadi di 34 provinsi $(100 \%)$ dan 436 kabupaten/kota (85\%). Secara nasional, pada tahun 2015 angka incidence rate (IR) sebesar 49,5 per 100.000 penduduk, tiga provinsi dengan IR tertinggi yaitu Bali $(208,7)$ diikuti Kalimantan Timur $(186,12)$ dan Kalimantan Utara $(120,08){ }^{2}$

Demam Berdarah Dengue memiliki penyebab yang bersifat multi faktor seperti virologis, penyebaran, lingkungan dan faktor manusia. ${ }^{3}$ Perilaku masyarakat berkontribusi nyata bagi penularan DBD melalui keberadaan habitat perkembangbiakan vektor pradewasa yang berada di lingkungan tempat tinggal. Meskipun demikian, masyarakat memiliki peran yang cukup penting mengeliminasi vektor sebagai langkah utama dalam upaya memutus rantai penularan untuk mencegah munculnya kasus di masa depan. Secara umum menurut Notoatmodjo, terbentuknya perilaku sehat seseorang sebagai pengaruh dari banyak faktor antara lain pengetahuan, sikap, pengalaman, keyakinan, sosial, budaya, sarana fisik, dan pengaruh atau rangsangan yang bersifat internal.

Perubahan perilaku sebagai bagian dari mobilisasi masyarakat terhadap tindakan pencegahan dengue merupakan salah satu dari tujuh rencana strategis penanganan dengue di Malaysia. ${ }^{6}$ Studi intervensi terhadap masyarakat di Nikaragua dan Meksiko menyimpulkan bahwa mobilisasi masyarakat dapat menambah keefektifan program pengendalian vektor dengue.

Kota Prabumulih merupakan salah satu wilayah yang dikategorikan endemis tinggi DBD di Provinsi Sumatra Selatan, selain Kota Palembang. Kota Prabumulih merupakan wilayah yang cukup strategis karena m e rupakan perlintasan antar kabupaten/kota di Sumatra Selatan. Kondisi tersebut menjadi faktor yang krusial dalam penularan dengue seperti yang ditunjukkan angka IR tahun 2012-2014 berturut-turut sebesar 180,3, 59,3, dan 130 per 100.000 penduduk. Tujuan penelitian ini adalah untuk mengetahui seberapa besar perubahan pada aspek pengetahuan, sikap dan perilaku sebelum dan sesudah intervensi pemberdayaan kader dan kelompok masyarakat

\section{BAHAN DAN METODE}

Penelitian ini dilaksanakan pada tahun 2014 yang berlokasi di tiga kelurahan (Patih Galung, Gunung Ibul dan Kelurahan Prabumulih) di Kota Prabumulih. Penelitian ini menggunakan disain eksperimen semu. Terdapat tiga jenis intervensi yang diberikan pada ketiga kelurahan tersebut yaitu di Kelurahan Prabumulih intervensi yang diberikan yaitu pemberdayaan masyarakat dalam bentuk kader jumantik yang dibekali larvasida serta intervensi penyuluhan kepada kelompok pengajian (intervensi I), di Kelurahan Patih Galung intervensi pemberdayaan kader jumantik (intervensi II) dan di Kelurahan Gunung Ibul tanpa diberikan intervensi atau sebagai daerah pembanding.

Kader jumantik yang direkrut di penelitian ini mayoritas adalah ibu rumah tangga yang mayoritas belum pernah menjadi kader jumantik. Daerah dengan intervensi pemberdayaan kader jumantik, sebelum melaksanakan tugasnya terlebih dahulu diberikan pelatihan tentang penyakit DBD dan aspek-aspek yang berkaitan dengan penularannya, pengenalan langsung stadium spesimen vektor penular (telur, larva, pupa dan imago) serta tugas dan tanggung jawab sebagai kader jumantik.

Bentuk intervensi penyuluhan bagi kelompok pengajian dalam bentuk penyuluhan sesaat setelah pengajian dilaksanakan. Konsepnya adalah dengan memberikan KIE (komunikasi, informasi dan edukasi) kepada anggota kelompok pengajian dan juga penggunaan audiovisual. Salah satu aspek penting yang diberikan saat penyuluhan adalah pengenalan masalah bersama dari hasil pemeriksaan jentik oleh kader. Harapan yang ingin dicapai dari pengenalan masalah tersebut adalah munculnya kesadaran atau perubahan sikap dan memicu perubahan perilaku.

Instrumen yang digunakan untuk mengukur pengetahuan, sikap dan perilaku responden yaitu kuesioner terstruktur. Jumlah sampel minimal yang dibutuhkan menggunakan rumus sebagai berikut: 
$n=\frac{\left\{Z_{1-\alpha / 2} \sqrt{2 \bar{P}(1-\bar{P})+} Z_{1-\beta} \sqrt{P_{1}\left(1-P_{1}\right)+P_{2}\left(1-P_{2}\right.}\right\}^{2}}{\left(P_{1}-P_{2}\right)^{2}}$

Keterangan :

$\mathrm{Z}_{1-\alpha / 2}=$ nilai distribusi normal baku pada $\alpha$

$\mathrm{Z}_{1-\beta} \quad=$ nilai distribusi normal baku pada $\beta$

$\mathrm{P}_{1} \quad=$ perkiraan proporsi pada populasi 1

$\mathrm{P}_{2} \quad=$ perkiraan proporsi pada populasi 2

$\overline{\mathrm{P}} \quad=\left(\mathrm{P}_{1}+\mathrm{P}_{2}\right) / 2$

Berdasarkan perhitungan rumus sampling tersebut jumlah sampel minimal adalah 93 dan untuk kepraktisan dibulatkan menjadi 100 responden. Pengukuran tingkat pengetahuan, sikap, dan perilaku (PSP) responden dilakukan sebelum dan sesudah intervensi. Aspek PSP yang ditanyakan kepada responden antara lain tentang gejala penyakit, cara penularan, vektor penular dan habitatnya, tindakan pencegahan, serta perilaku keseharian terkait risiko terkena gigitan nyamuk. Tingkat PSP responden diolah menurut kategori baik, cukup dan buruk. Kategori pengetahuan atau sikap atau perilaku yang baik apabila skor $\geq 75$, kategori cukup 50-74 dan kateori buruk $<50$.

\section{HASIL}

Karakteristik responden penelitian yang terdiri dari umur, jenis kelamin, pendidikan dan pekerjaan ditampilkan pada Tabel 1. Mayoritas responden berada pada kelompok umur 31 - 45 tahun, berjenis kelamin perempuan, tingkat pendidikan tamat SMA sederajat, dan pekerjaan ibu rumah tangga.

Tabel1. Karakteristik responden penelitian yang berasal dari tiga kelurahan di Kota Prabumulih.

\begin{tabular}{|c|c|c|c|c|c|c|c|c|}
\hline \multirow{3}{*}{ No. } & & & \multicolumn{6}{|c|}{ Jumlah responden (per } \\
\hline & \multicolumn{2}{|c|}{ Karakteristik Demografi } & \multicolumn{2}{|c|}{ Prabumulih } & \multicolumn{2}{|c|}{ Patih Galung } & \multicolumn{2}{|c|}{ Gunung Ibul } \\
\hline & & & Sebelum & Sesudah & Sebelum & Sesudah & Sebelum & Sesudah \\
\hline \multirow{3}{*}{1} & & $31-45$ & 39 & 39 & 62 & 54 & 49 & 45 \\
\hline & & $46-60$ & 31 & 28 & 23 & 22 & 33 & 30 \\
\hline & & Sub total & 118 & 111 & 114 & 103 & 118 & 108 \\
\hline \multirow[t]{3}{*}{2} & Jenis kelamin & Laki-laki & 21 & 21 & 18 & 16 & 28 & 25 \\
\hline & & Perempuan & 97 & 90 & 96 & 87 & 90 & 83 \\
\hline & & Sub total & 118 & 111 & 114 & 103 & 118 & 108 \\
\hline \multirow{3}{*}{3} & & SMA sederajat & 61 & 49 & 48 & 53 & 28 & 28 \\
\hline & & Perguruan Tinggi & 8 & 9 & 15 & 9 & 41 & 33 \\
\hline & & Sub total & 118 & 111 & 114 & 103 & 118 & 108 \\
\hline \multirow[t]{5}{*}{4} & Pekerjaan & tidak bekerja & 20 & 19 & 1 & 2 & 5 & 5 \\
\hline & & Pelajar/mahasiswa & 1 & 1 & 3 & 3 & 6 & 7 \\
\hline & & Ibu rumah tangga & 53 & 51 & 65 & 59 & 43 & 43 \\
\hline & & PNS/TNI/POLRI/ BUMN/BUMD & 3 & 1 & 5 & 7 & 34 & 27 \\
\hline & & Swasta & 4 & 7 & 8 & 3 & 3 & 3 \\
\hline
\end{tabular}


Hasil pengukuran pengetahuan, sikap dan perilaku sebelum dan sesudah intervensi di Kelurahan Prabumulih yang ditampilkan pada Gambar 1 menunjukkan terjadi perubahan persentase PSP antara sebelum dan sesudah intervensi. Responden dengan PSP kategori baik menunjukkan peningkatan persentase, sedangkan PSP responden dengan kategori cukup dan buruk terjadi peningkatan dan penurunan. Peningkatan persentase responden dengan kategori buruk paska intervensi terjadi pada aspek sikap. Kelurahan Prabumulih merupakan wilayah yang diintervensi dengan pemberdayaan kader (plus larvasidasi selektif) dan penyuluhan pada kelompok ibu-ibu pengajian.

Gambar 2 menampilkan hasil pengukuran pengetahuan, sikap dan perilaku sebelum dan sesudah intervensi di Kelurahan Patih Galung. Intervensi di kelurahan ini adalah pemberdayaan kader jumantik (tanpa larvasidasi selektif). Terjadi penurunan persentase responden untuk kategori baik pada aspek pengetahuan paska intervensi. Untuk responden dengan kategori PSP cukup,

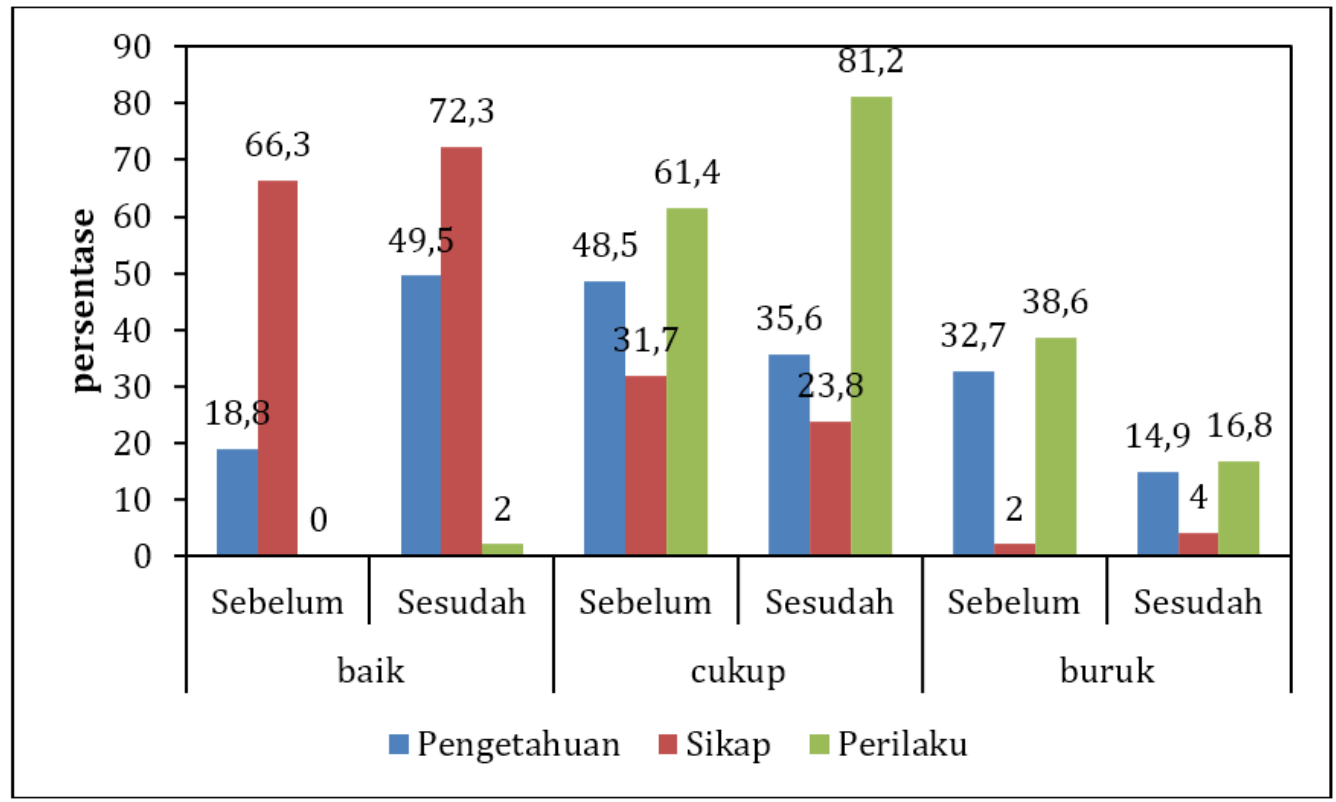

Gambar 1. Tingkat pengetahuan, sikap dan perilaku responden tentang penyakit demam berdarah dengue sebelum dan sesudah intervensi di Kelurahan Prabumulih, Kota Prabumulih.

penurunan terjadi pada aspek pengetahuan dan sikap, sedangkan pada responden dengan kategori buruk kenaikan persentase didapatkan pada aspek sikap.

Hasil pengukuran pengetahuan, sikap, dan perilaku sebelum dan sesudah intervensi di Kelurahan Gunung Ibul yang ditampilkan pada Gambar 3 menunjukkan terjadi peningkatan persentase responden kategori baik pada aspek sikap, dan perilaku, sedangkan pada responden dengan kategori buruk terjadi penurunan persentase pada aspek pengetahuan dan perilaku namun memperlihatkan kenaikan pada aspek sikap.

Hasil analisis statistik sebelum dan sesudah intervensi di Kelurahan Prabumulih, Patih Galung dan Gunung Ibul di Kota
Prabumulih ditampilkan pada Tabel 2. Hasil uji statistik tersebut menunjukkan di Kelurahan Prabumulih terdapat perbedaan sebelum dan sesudah intervensi untuk aspek pengetahuan dan perilaku, untuk Kelurahan Patih Galung tidak memperlihatkan perbedaan sebelum dan sesudah intervensi baik untuk pengetahuan, sikap maupun perilaku, sedangkan Kelurahan Gunung Ibul sebagai lokasi tanpa intervensi menunjukkan perbedaan nyata antara pengukuran pertama dan kedua pada aspek perilaku.

Hasil analisis statistik sebelum dan sesudah intervensi di Kelurahan Prabumulih, Patih Galung dan Gunung Ibul di Kota Prabumulih ditampilkan pada Tabel 2. Hasil uji statistik tersebut menunjukkan di 


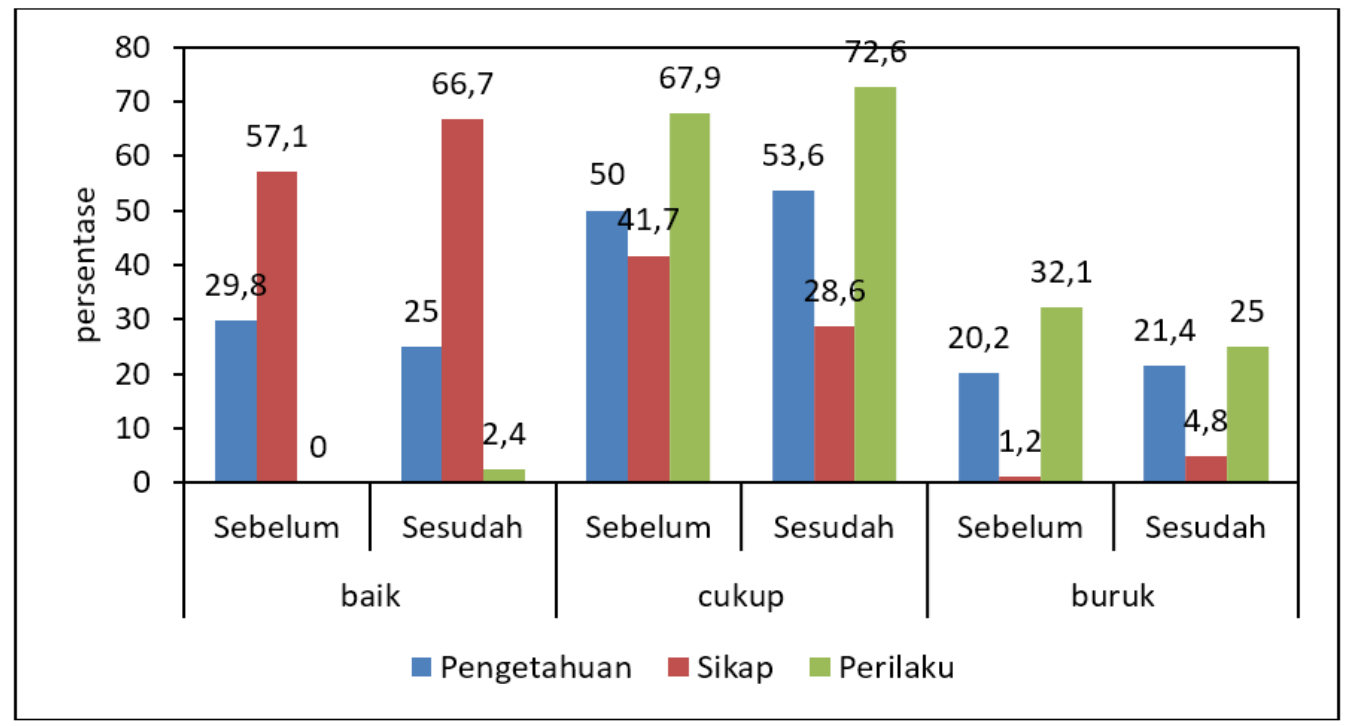

Gambar 2. Tingkat pengetahuan, sikap dan perilaku responden tentang penyakit demam berdarah dengue sebelum dan sesudah intervensi di Kelurahan Patih Galung, Kota Prabumulih.

Kelurahan Prabumulih terdapat perbedaan sebelum dan sesudah intervensi untuk aspek pengetahuan dan perilaku, untuk Kelurahan Patih Galung tidak memperlihatkan perbedaan sebelum dan sesudah intervensi baik untuk pengetahuan, sikap maupun perilaku, sedangkan Kelurahan Gunung Ibul sebagai lokasi tanpa intervensi menunjukkan perbedaan nyata antara pengukuran pertama dan kedua pada aspek perilaku.

\section{PEMBAHASAN}

Demam berdarah dengue adalah penyakit berbasis lingkungan dimana vektor dengue, pengetahuan dan perilaku manusia berperan sangat penting dalam terjadinya penularan. Penelitian yang dilakukan di daerah pinggiran Vientiane ibu kota Laos, menunjukkan rendahnya tingkat pengetahuan dan perilaku masyarakat terkait

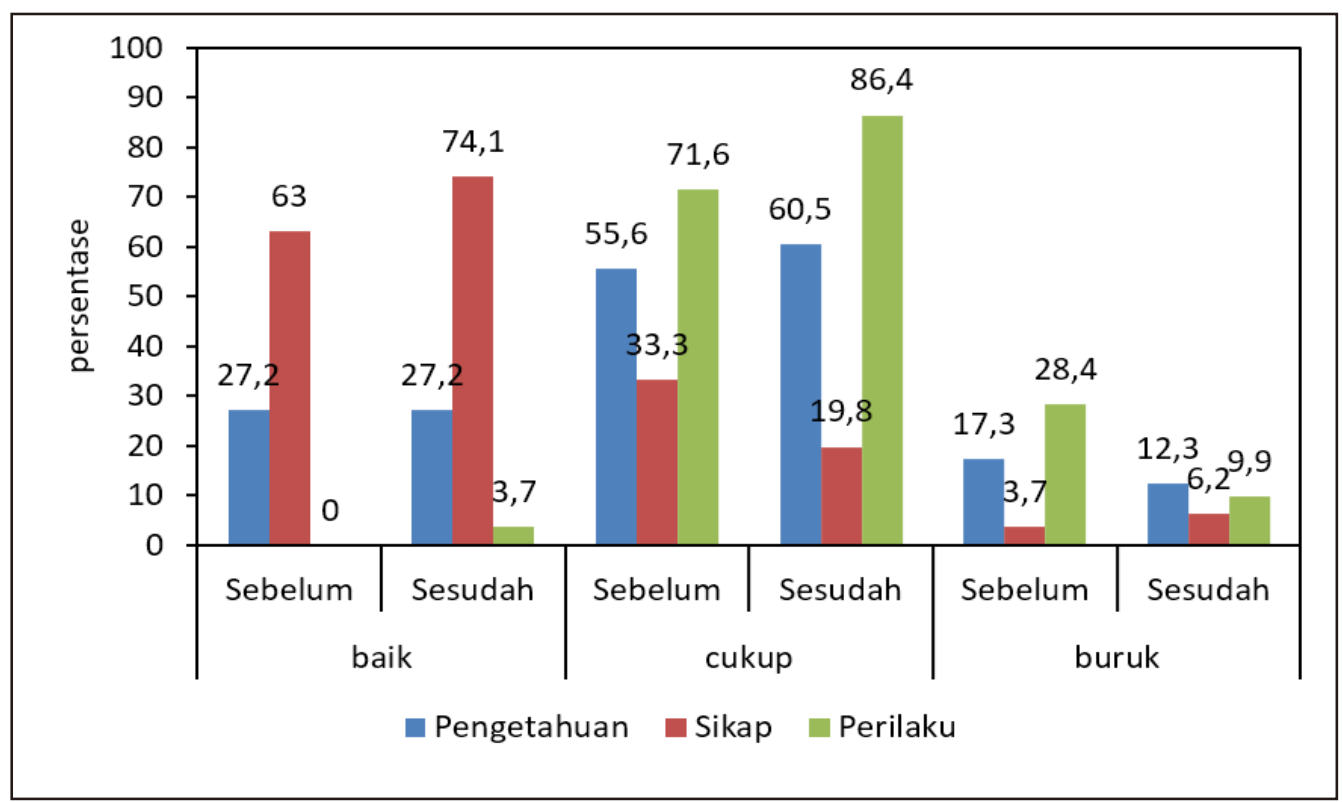

Gambar 2. Tingkat pengetahuan, sikap dan perilaku responden tentang penyakit demam berdarah dengue sebelum dan sesudah intervensi di Kelurahan Patih Galung, Kota Prabumulih. 
Tabel 2. Hasil uji statistik tingkat pengetahuan, sikap dan perilaku sebelum dan sesudah intervensi di Kota Prabumulih.

\begin{tabular}{lccc}
\hline \multirow{2}{*}{ Aspek } & \multicolumn{3}{c}{ Kelurahan } \\
\cline { 2 - 4 } & Prabumulih & Patih Galung & Gunung Ibul \\
\hline Pengetahuan & $0,000^{*}$ & 0,737 & 0,138 \\
Sikap & 0,955 & 0,484 & 0,681 \\
Perilaku & $0,000^{*}$ & 0,054 & $0,000^{*}$ \\
\hline
\end{tabular}

Keterangan :

*Perbedaan bermakna menurut uji Mann Whitney pada taraf kepercayaan 95\%

DBD dan kondisi ini diduga berhubungan dengan keberadaan larva yang cukup tinggi pada tahun-tahun sebelumnya (House Index 91\%). Penelitian potong lintang di Kolombia, $81,3 \%$ responden (total 309 orang) menyatakan tidak mengetahui siklus perkembangbiakan nyamuk namun mereka menyadari apabila mengeliminasi habitat perkembangbiakan yang mengandung air dapat membantu upaya pencegahan penularan, meskipun demikian House Index yang diperoleh sebesar 40,3\%.

Mayoritas responden penelitian ini adalah perempuan, informasi tentang kebiasaan sehari-hari terkait penyimpanan dan penggunaan air di rumah tangga lebih diketahui oleh perempuan khususnya ibu rumah tangga. Meskipun saat ini peranan wanita atau istri turut membantu mencari nafkah bagi keluarga, namun urusan rumah tangga masih menjadi tanggung jawab utama seorang istri. Penelitian yang dilakukan oleh Ernaningsih dan Samawati di Kota Palembang terhadap 200 orang responden yang telah menikah, diketahui jika istri tetap memiliki peran utama dalam mengurus rumah tangga dan merawat serta mendidik anak meskipun ketika istri juga berperan meniti karir atau mencari nafkah. ${ }^{10}$

Kelurahan Prabumulih sebagai daerah intervensi I, mengalami peningkatan aspek pengetahuan, sikap dan perilaku pascaintervensi, namun secara statistik hanya aspek pengetahuan dan perilaku yang menunjukkan perbedaan yang bermakna antara sebelum dan sesudah intervensi. Mayoritas responden penelitian adalah berjenis kelamin perempuan dan usia lebih dari 30 tahun, kondisi ini dapat diduga menjawab terjadinya peningkatan pengetahuan dan perilaku responden karena intervensi yang diberikan yaitu promosi kesehatan tentang penyakit DBD melalui kelompok masyarakat dalam hal ini kelompok ibu-ibu pengajian. Selain itu, kunjungan rutin kader jumantik yang melakukan pemeriksaan jentik secara berkala dapat berkontribusi kepada peningkatan pengetahuan, sikap maupun perilaku masyarakat.

Promosi kesehatan dalam bentuk pemutaran media audiovisual menunjukkan antusiasme yang cukup tinggi dari masyarakat (anggota kelompok pengajian), meskipun tayangan yang ditampilkan dalam bentuk animasi. Perilaku (yang benar) dalam mencegah penularan DBD diharapkan akan menambah pengetahuan, memicu kesadaran dan pada akhirnya memunculkan perilaku yang positif. Pendekatan promosi kesehatan kepada masyarakat melalui pendekatan media audiovisual kepada siswa sekolah menengah (umur 14 - 16 tahun) di Kolkata, India berdampak positif terhadap peningkatan pengetahuan tentang demam berdarah walaupun perlu dikaji lebih jauh tentang perubahan perilaku dan kontribusinya untuk memicu kewaspadaan masyarakat. ${ }^{11}$ Dampak positif dari penyuluhan menggunakan media audiovisual juga didapatkan pada upaya peningkatan perilaku hidup 
bersih dan sehat (PHBS) terhadap peningkatan pengetahuan masyarakat dalam menanggulangi penyakit diare. ${ }^{12}$

Penelitian pemberdayaan masyarakat di Provinsi Guangdong, Cina memperlihatkan hasil yang positif, nilai Breteau Index (BI) menurun cukup drastis pascaintervensi dengan kisaran nilai BI 0 hingga $<7,5 .^{13}$ Studi intervensi di Kota Prabumulih ini memberdayakan kader jumantik (baik yang lama ataupun baru ditunjuk) dan seluruhnya adalah perempuan. Kajian yang dilakukan oleh Gunn et al. tentang pemberdayaan perempuan dalam pengendalian vektor menunjukkan bahwa kaum perempuan berpotensi dilibatkan program pengendalian vektor di tingkat masyarakat. ${ }^{14}$ Berdasarkan kajian tersebut dan hasil penelitian di Guangdong, Cina mengindikasikan pengendalian vektor berbasis masyarakat dapat menjadi model atau program yang memiliki daya ungkit untuk mengendalikan penyakit DBD dan terintegrasi dengan program pengendalian vektor lainnya.

Penelitian tentang partisipasi organisasi sosial lokal dalam pembangunan kesejahteraan sosial di Kota Ambon, kegiatan keagamaan seperti kelompok Majelis Ta'lim dan Angkatan Muda, serta kelompok atas kekerabatan dan ketetanggaan yang dijalin melalui kegiatan arisan maupun kelompok lainnya, mampu menggerakkan kelompok secara mandiri untuk peduli terhadap berbagai macam permasalahan yang ada di sekitarnya. ${ }^{15}$

Kelurahan Patih Galung sebagai wilayah intervensi II (pemberdayaan kader jumantik), hasil pengukuran KAP menunjukkan terjadi peningkatan maupun penurunan aspek KAP pada masing-masing kategori (baik, cukup, buruk). Pemeriksaan jentik secara berkala oleh kader mempunyai dua tujuan yaitu mengetahui tingkat kepadatan jentik vektor dan berperan sebagai agen promosi kesehatan. Promosi kesehatan yang dimaksud adalah kader diharapkan melaksanakan fungsi komunikasi, informasi dan edukasi (KIE) saat melakukan kunjungan pemeriksaan jentik. Wawancara spontan (tidak terstruktur) terhadap kader yang dilibatkan dalam penelitian ini, beberapa orang kader menyatakan tidak pede (percaya diri) dalam melaksanakan tugasnya terutama atas pertanyaan-pertanyaan yang diterima dari pemilik rumah yang diperiksa. Pengetahuan yang benar tentang penyakit DBD dan pencegahannya wajib dikuasai oleh kader untuk memberikan informasi, mempengaruhi dan memotivasi masyarakat.

Kelurahan Gunung Ibul sebagai daerah pembanding secara umum memperlihatkan kenaikan persentase KAP antara pengukuran pertama dan kedua terutama pada aspek perilaku untuk kategori baik dan sedang. Sebaliknya perilaku responden dengan kategori buruk mengalami penurunan. Kondisi ini menunjukkan perubahan perilaku pada responden dengan kategori buruk menjadi sedang ataupun baik dan secara statistik menunjukkan perbedaan yang signifikan. Masyarakat di Kelurahan Gunung Ibul relatif memiliki perbedaan karakteristik dibandingkan responden di Kelurahan Prabumulih maupun Patih Galung, seperti pada jenis pekerjaan maupun tingkat pendidikan (Tabel 1). Tidak diperoleh informasi mengenai kegiatan yang berkaitan dengan program pengendalian vektor (promosi kesehatan, dsb.), sehingga diduga perubahan perilaku terjadi sebagai dampak dari informasi yang diperoleh responden dari berbagai sumber (media massa, media elektronik, sekolah, teman/keluarga, dsb.).

\section{KESIMPULAN}

Terdapat perbedaan yang bermakna terhadap aspek pengetahuan dan perilaku di daerah intervensi I, namun aspek perilaku menunjukkan hal yang berbeda. Kelompok masyarakat lokal seperti kelompok pengajian, arisan, karang taruna dan sebagainya dapat menjadi sasaran efektif untuk meningkatkan pengetahuan tentang aspek pencegahan penyakit DBD, menimbulkan kesadaran dan memicu terjadinya perubahan perilaku secara kolektif.

\section{SARAN}

Penggunaan media audiovisual dalam promosi kesehatan perlu memperhatikan konten maupun jenisnya yang diselaraskan dengan karakteristik sasaran (masyarakat) yang akan dituju.

\section{UCAPAN TERIMA KASIH}

Ucapan terima kasih disampaikan kepada Kepala Balai Litbangkes Baturaja atas 
kesempatan yang diberikan untuk memimpin penelitian. Ucapan terima kasih juga disampaikan kepada Dinas Kesehatan Kota Prabumulih dan UPT Puskesmas yang memberikan dukungan selama penelitian berlangsung. Tim penulis juga menyampaikan terima kasih kepada Bapak Santoso, S.K.M., M.Sc. dan Yahya, S.K.M., M.Si. yang telah memberikan telaah terhadap karya tulis ilmiah ini.

\section{DAFTAR PUSTAKA}

1. World Health Organization. Global alert and response -impact of dengue.

2. Pusat Data dan Informasi Kementerian Kesehatan RI. Situasi DBD di Indonesia. Jakarta; 2016.

3. Kusriastuti R, Sutomo S. Evolution of dengue prevention and control programme in Indonesia. Dengue Bull. 2005;29:1-7.

4. Kurniawan ME, Mohamed AMD, Siyam N, Fatikha N, Fitriani NA. Relation Between Knowledge and Attitude Regarding DHF with PSN Behavior Among the Community Around the Campus.J Kesehat Masy. $2017 ; 13$ ( 2 ): $145-151$. doi:10.15294/kemas.v13i2.12069

5. Notoatmodjo S. Pendidikan dan Perilaku Kesehatan. Jakarta: Rineka Cipta; 2003.

6. Mudin RN. Dengue Incidence and the Prevention and Control Program in Malaysia. Int Med J Malaysia. 2015;14(1):05-10. doi:10.1097/00004311-199603410-00003

7. Andersson N, Nava-Aguilera E, Arosteguí J, et al. Evidence based community mobilization for dengue prevention in Nicaragua and Mexico (Camino Verde, the Green Way): Cluster randomized controlled trial. BMJ. 2015;351:32-67. doi:10.1136/bmj.h3267

8. Mayxay M, Cui W, Thammavong S, et al. Dengue in peri-urban Pak-Ngum district, Vientiane capital of Laos: A community survey on knowledge, attitudes and practices.
BMC Public Health. 2013;13(434):1-8. doi:10.1186/1471-2458-13-434

9. Jaramillo Ramírez GI, Álvarez LSB. Knowledge, Attitudes and Practices Regarding Dengue, Chikungunya, and Zika and their Vector Aedes Aegypti in Villavicencio, Colombia. Open Public Health J. 2017 ; 10 ( 1 ) : $80-89$. doi:10.2174/1874944501710010080

10. Ernaningsih W, Samawati P. Persepsi Masyarakat Kota Palembang Tentang Rekonstruksi Pasal Mengenai Pembagian Peran Antara Suami dan Istri Dalam UndangUndang No.1 Tahun 1974 Tentang Perkawinan. J Huk Simbur Cahaya. 2017;24(2):4772-4789.

11. Dasgupta A, Biwas R, Parthasarathi R, Ramprabhakar V, Ray S, Das A. Evaluation of an audiovisual based health education programme on dengue fever among midadolescent school boys during an outbreak in Kolkata. Int J Med Sci Clin Invent. 2014;1(5):163-182.

12. Mawan AR, Indriwati SE, Suhadi. Pengembangan video penyuluhan perilaku hidup bersih dan sehat (PHBS) bermuatan nilai karakter terhadap peningkatan pengetahuan masyarakat dalam Menanggulangi penyakit diare. J Pendidik. 2017;2(7):883-888.

13. Lin H, Liu T, Song T, et al. Community Involvement in Dengue Outbreak Control: An Integrated Rigorous Intervention Strategy. PLoS Negl Trop Dis. 2016;10(8):1-10. doi:10.1371/journal.pntd.0004919

14. Gunn JKL, Ernst KC, Center KE, et al. Current strategies and successes in engaging women in vector control: a systematic review. $B M J$ Glob Heal. $2018 ; 3$ (1): $1-10$. doi:10.1136/bmjgh-2017-000366

15. Kurniasari A. Partisipasi organisasi sosial lokal dalam pembangunan kesejahteraan sosial. J Penelit dan Pengemb Kesejaht Sos. 2006;11(3):40-54. 